Check for updates

Cite this: RSC Adv., 2018, 8, 29013

\title{
Detection of chymase activity using a specific peptide probe conjugated onto gold nanoparticles $\uparrow$
}

\author{
Hui-Fang Chang,,$^{\text {ab }}$ Yu-Ling Sun,,$^{c}$ Fang-Yuan Yeh, ${ }^{a}$ I-Hua Tseng, (D) a \\ Chia-Chu Chang ${ }^{\text {defgh }}$ and Chih-Sheng Lin (D) *a
}

Gold nanoparticles (AuNPs) can be applied in biosensors using fluorescence resonance energy transfer (FRET) technique. Based on this technique, we have established a sensitive and efficient biosensing method by modifying a peptide-probe onto AuNPs to detect proteinase enzyme activity in this study. This biosensing method was designed for chymase activity detection and applied in kidney disease diagnosis. In this study, $16 \mathrm{~nm}$-AuNPs were used to construct the AuNPs-based fluorescence peptide probe (named AuNPs-peptide probe) for chymase activity determination. The peptide sequence is FITCAcp-DRVYIHPFHLDDDDDC, which comprises a fluorophore at the N-terminal end, an enzyme (chymase) substrate (DRVYIHPFHL), a spacer (DDDDD) and cysteine (C) to conjugate to AuNPs surface. When the enzyme catalyzes the substrate sequence, the fluorophore drifts away from AuNPs and the fluorescence emitting signal can be excited at $495 \mathrm{~nm}$ and detected at $515 \mathrm{~nm}$. The results indicate that the time required for the AuNPs-peptide probe for activity detection of chymase was only 15 min, and a linear correlation from 10 to $100 \mathrm{ng} \mathrm{mL}^{-1}$ of chymase was acquired. The chymase reaction would be significantly inhibited by addition of specific chymase inhibitor chymostatin. The AuNPs-peptide probe was tested for the detection of high concentrations of trypsin and chymotrypsin, but only minor emitted fluorescence intensity was detected. According to these results, sensitivity and specificity of the AuNPspeptide probe for chymase detection have been confirmed. AuNPs-peptide probe was successfully used for the detection of renal chymase activity; and the results indicate the pathogenically increased chymase activity in kidney tissue of nephropathic mice from aristolochic acid I treatment.

Received 21st May 2018

Accepted 27th July 2018

DOI: 10.1039/c8ra04322a

rsc.li/rsc-advances fluorescence resonance energy transfer (FRET). ${ }^{6-8}$ FRET is a physical phenomenon where energy created by fluorescence excitation of one molecule is transferred to an adjacent molecule. Based on the FRET technique, numerous biosensor platforms have been developed. ${ }^{9,10}$ AuNPs have been employed to establish biosensing platforms through conjugation with several types of biomolecules, such as nucleic acids, peptides, antibodies and enzymes. ${ }^{\mathbf{1 1 - 1 3}}$ In these molecules, peptides with specific sequences are the most common choice because of convenience of design and manipulation. ${ }^{13-16}$

The bioactivity of chymase is similar to that of angiotensinconverting enzyme (ACE) that converts angiotensin I (Ang I) to angiotensin II (Ang II) in the renin-angiotensin system (RAS) to activate Ang II/AT1R (Ang II type I receptor) axis-related signaling pathways. ${ }^{17}$ Chymase belongs to the chymotrypsin family of serine proteinases. ${ }^{18}$ In previous studies, chymase expression increased in renal tissue in various kidney diseases. ${ }^{19-21}$ This high level of chymase may be expressed from mast cells in the diseased tissue of kidneys. ${ }^{22,23}$ Several chymase assays have been commonly used, including spectrophotometric, fluorophotometric and high-performance liquid chromatographic (HPLC) methods. ${ }^{24-26}$ However, they are often time consuming, expensive, or have low sensitivity. With the rise of 
nanotechnology, several types of nanoparticles have been widely used in biosensors, among which AuNPs are the most popular. Owing to their unique physical attribute of conjugating with small molecules, we established an AuNPs-based fluorescence biosensor platform, which modified the FITC-labeled peptide onto AuNPs as the proteinase substrate. ${ }^{7}$ Due to the quenching effect of AuNPs, once the enzyme catalyzes the substrate, the labeled FITC drifts away from the AuNPs surface, thus recovering the fluorescence signal (ESI Fig. S1 $\dagger$ ). In the present study, the platform was modified and extensively applied in the detection of chymase in tissue homogenate. Additionally, the platform was used to study chronic kidney disease induced by aristolochic acid I (AAI), which found in a Chinese herb.

\section{Materials and methods}

\section{Chemicals}

All chemicals were of analytical grade. Sodium citrate $\left(\mathrm{C}_{6} \mathrm{H}_{5}\right.$ $\left.\mathrm{Na}_{3} \mathrm{O}_{7} \cdot 2 \mathrm{H}_{2} \mathrm{O}\right)$, sodium chloride $(\mathrm{NaCl})$, hydrogen tetrachloroaurate (III) $\left(\mathrm{HAuCl}_{4} \cdot 3 \mathrm{H}_{2} \mathrm{O}\right)$, aristolochic acid I (AAI; \#A5512), chymotrypsin (\#C4129), trypsin (\#T4665), chymostatin (\#C7268), chymase (\#C8118), and DL-dithiothreitol (DTT; \#D5545) were purchased from Sigma-Aldrich (St. Louis, MO, USA). Chymase antibody (\#GTX105829) and $\beta$-actin (GTX109639) were purchased from GeneTex (Irvine, CA, USA). Horseradish peroxidase (HRP) labeled secondary antibody (goat anti-rabbit IgG, \#sc2004) was purchased from Santa Cruz Biotechnology (Santa Cruz, CA, USA).

\section{Peptide substrates}

Fluorescein isothiocyanate (FITC) labeled peptide was commercially synthesized by Genesis Biotech (Taipei, Taiwan) and used for self-assembled AuNPs biosensing platform. The sequence of this FITC labeled peptide is FITC-AcpDRVYIHPFHLDDDDDC. The peptide substrate (DRVYIHPFHL) detects chymase and its sequence is the same as Ang I. This peptide substrate was conjugated with Acp as a spacer and FITC as fluorophore at the N-terminal. Five negatively charged aspartic acid molecules (D) decrease the steric barrier and enhance the signal. The last residue, viz., cysteine at the Cterminal, conjugates to AuNPs surface through $\mathrm{Au}-\mathrm{S}$ bond. The pI of the peptide was calculated by the free online tool, Peptide Property Calculator. The peptide $(\mathrm{pI}=3.98)$ can be conjugated onto AuNPs in self-assembly manner at room temperature and $\mathrm{pH} 5.6$ to form AuNPs-peptide probe (ESI Table S1†).

\section{Synthesis of AuNPs}

AuNPs were prepared by citrate reduction method according to the reported protocol. ${ }^{12}$ A $50 \mathrm{~mL}$ aqueous solution in a conical flask containing $1.0 \mathrm{mM}$ chloroauric acid was heated to a vigorous boil with stirring. Then, $38.8 \mathrm{mM}$ sodium citrate solution $(5 \mathrm{~mL})$ was rapidly added to the solution. The solution was boiled for another $15 \mathrm{~min}$ and the color changed from pale yellow to deep red. The solution was cooled to room temperature with continuous stirring.

Sizes of AuNPs were measured by BI-200SM Goniometer, which is a dynamic light scattering (DLS) system (Brookhaven Instruments Corporation, Holtsville, NY, USA). DLS is a technique that can be used to determine the size distribution profile of small particles in solution. Brownian motion of small particles causes a Doppler shift in the frequency of incident light, which can be related to size of the particles. Absorbance of the as-synthesized AuNPs was recorded by a UV-Vis spectrophotometer (SpectraMax 190, Molecular Devices Corporation, Sunnyvale, CA, USA) from 400 to $700 \mathrm{~nm}$ at $1 \mathrm{~nm}$ intervals. The as-produced 15-17 nm citrate-stabilized AuNPs were preserved at $4{ }^{\circ} \mathrm{C}$ until further application.

\section{Preparation of AuNPs-peptide probe}

The FITC-labeled peptide was immobilized on AuNPs through the thiol group (-SH) of cysteine (Cys) at C-terminal. The optical density of the as-produced 15-17 nm AuNPs solution was measured at $520 \mathrm{~nm}\left(\mathrm{OD}_{520}\right)$ and then, the optical density was adjusted with sterilized water to $\mathrm{OD}_{520}=1.0$. Then, $980 \mu \mathrm{L}$ of $2.5 \mathrm{nM}$ AuNPs was mixed with $10 \mu \mathrm{L}$ of $1 \mathrm{mg} \mathrm{mL}{ }^{-1}$ FITC-labeled peptide and $10 \mu \mathrm{L}$ of $0.01 \mathrm{M}$ phosphate buffer containing $0.1 \%$ SDS and $0.3 \mathrm{M} \mathrm{NaCl}$. The AuNPs-peptide probe solution was shaken for $12 \mathrm{~h}$ at $40 \mathrm{rpm}$ at room temperature in the dark. Then, $10 \mu \mathrm{L}$ of $0.1 \mathrm{mM}$ 6-mercaptohexan-1-ol (MCH) was added for another $2 \mathrm{~h}$ with constant shaking. ${ }^{27}$ Before using the AuNPs-peptide probe, it was centrifuged (10 $000 \mathrm{rpm}, 20 \mathrm{~min}$ at $4{ }^{\circ} \mathrm{C}$ ) to exclude excess FITC-labeled peptide that was not modified onto AuNPs. The supernatant was carefully removed and $1000 \mu \mathrm{L}$ sterilized water was added.

\section{Gel electrophoresis of AuNPs}

Gel electrophoresis was performed to confirm the change in color of AuNPs after modification and enzyme digestion. ${ }^{\mathbf{1 2}}$ Visible color changes in AuNPs red band and UV light excited fluorescence band could be observed. Furthermore, 1.5\% agarose gel was prepared with working TBE buffer (45 mM Trisborate/1 mM EDTA). All samples were prepared with 35\% glycerol at ratio of $7: 1$ for increasing the density. Furthermore, a small amount of $10 \%$ SDS $(1 \mu \mathrm{L})$ was added to the bare AuNPs to help the AuNPs move toward the positive electrode. Horizontal electrophoresis system was used, and the gel was run for $30 \mathrm{~min}$ at $110 \mathrm{~V}$ in working TBE buffer. Images were collected by digital camera under both white light and UV light.

\section{Confirmation of peptide substrates conjugated onto AuNPs}

In order to calculate conjugation efficiency of FITC-labeled peptide onto AuNPs, it is necessary to utilize a compound that can displace the FITC-labeled peptide immobilized on AuNPs. DTT is widely used for AuNPs-based platforms to separate molecules or ligands from the AuNPs surface ${ }^{28}$ because DTT is a small, compact molecule with very high affinity towards AuNPs owing to the two thiol groups $(-\mathrm{SH})$ that allow it to easily penetrate and conjugate to AuNPs. It is believed that DTT added 
in excess can completely displace most molecules or ligands immobilized on AuNPs.

In this study, the FITC-labeled peptide was quantified by measuring the fluorescence intensity using a fluorescence spectrophotometer (F-2700; Hitachi, Tokyo, Japan). DTT displacement experiment was conducted by adding $500 \mu \mathrm{L}$ DTT (50 mg mL ${ }^{-1}$, dissolved in 0.1 M PB buffer (pH 6.5)), to AuNPspeptide probe sediment $(0.625 \mathrm{nM})$ for $12 \mathrm{~h}$ at room temperature. The fluorescence intensity of a certain volume FITClabeled peptide was recorded with desired dilutions, and a linear correlation between concentration of FITC-labeled peptide and fluorescence intensity was obtained. The supernatant was centrifuged and the AuNPs-peptide probe sediment after DTT-displacement was processed by the same procedures to obtain the linear correlation. Fluorescence intensity was detected at $515 \mathrm{~nm}$ with excitation wavelength of $495 \mathrm{~nm}$ (ex.) em. $=495 / 515 \mathrm{~nm})$.

\section{Chymase activity assay by AuNPs-peptide probe}

The chymase activity assay was conducted using a total volume of $250 \mu \mathrm{L}$, comprising AuNPs-peptide probe (FITC-AcpDRVYIHPFHLDDDDDC-AuNPs; $125 \mu \mathrm{L}$ ), reactive buffer (TTC buffer; $50 \mathrm{mM}$ Tris, $10 \mathrm{mM} \mathrm{CaCl}_{2}, 150 \mathrm{mM} \mathrm{NaCl}$ and $0.05 \%$ Brij $35, \mathrm{pH} 8$ ), and sample containing chymase, proteinase or kidney tissue homogenate. The samples were incubated for $15 \mathrm{~min}$ at $37{ }^{\circ} \mathrm{C}$. Fluorescence intensity was recorded and analyzed at $515 \mathrm{~nm}$ with excitation wavelength of $495 \mathrm{~nm}$ (ex./em. $=495 /$ $515 \mathrm{~nm}$ ) by a fluorescence spectrophotometer.

\section{Chymase inhibition assay}

The inhibition study was carried out with chymostatin, a chymase inhibitor, in total volume of $250 \mu \mathrm{L}$, containing AuNPspeptide probe, reactive buffer (TTC buffer, $\mathrm{pH}$ 8), chymase and chymostatin. Different concentrations of chymostatin ( 5 to $50 \mu \mathrm{M}$ ) were added to the reaction solution and incubated for $15 \mathrm{~min}$ at $37^{\circ} \mathrm{C}$. Fluorescence intensity was recorded (ex./em. =
$495 / 515 \mathrm{~nm}$ ) by a fluorescence spectrophotometer and then, the inhibition rate of chymase activity was calculated.

\section{Animal study of AAI-induced kidney injury}

C57BL/6 mice were divided into 2 groups ( $n=9$ in each group): a group with disease development from AAI treatment and a group of Sham control. The mice in AAI group were treated with a dose of $10 \mathrm{mg}$ per $\mathrm{kg}$ per 3 days AAI (accumulated dose of $\left.100 \mathrm{mg} \mathrm{kg}{ }^{-1}\right)$ via i.p. injection for a period of 28 days (0-4 weeks), and then sacrificed after another 28 days (total of 8 weeks for experiment). The Sham control mice were treated with pH 7.4 PBS and sacrificed on day 56. The experimental protocols conformed to the Guide for the Care and Use of Laboratory Animals published by National Institutes of Health $(\mathrm{NIH}$ Publication, $8^{\text {th }}$ edition, 2011) and were approved by the animal welfare committees of National Chiao Tung University, Taiwan. The number of mice used in this study was evaluated and minimized with best effort.

Mice urine was collected in a metabolism cage for $24 \mathrm{~h}$ before animals were sacrificed. After experiments, the mice were sacrificed after anesthetization by injection of avertin (250 $\mathrm{mg} \mathrm{kg}^{-1}$ ), and blood was collected by direct cardiac puncture. The blood samples without adding heparin were centrifuged $\left(3000 \mathrm{~g}, 15 \mathrm{~min}\right.$ at $4{ }^{\circ} \mathrm{C}$ ) to acquire serum (supernatants). The kidney tissues were excised after perfusion with $0.9 \% \mathrm{NaCl}$ solution. All of the urine, serum and tissue samples were stored at $-80{ }^{\circ} \mathrm{C}$ until use. To evaluate renal function of the experimental mice, the levels of creatinine, albumin and blood urea nitrogen in urine and serum were measured using a Fujifilm clinical chemical analyzer (Dri-Chem 3500i; Fujifilm, Tokyo, Japan).

\section{Tissue protein extraction and Western blot}

Weighed kidney samples (200 mg) were homogenized with lysis buffer PRO-PREPTM Protein Extraction Solution (iNtRON Biotechnology, Kyungki-Do, Korea). The samples were centrifuged $\left(12000 \mathrm{~g}, 10 \mathrm{~min}\right.$ at $\left.4{ }^{\circ} \mathrm{C}\right)$ to separate supernatants from
A. UV spectra of AuNPs

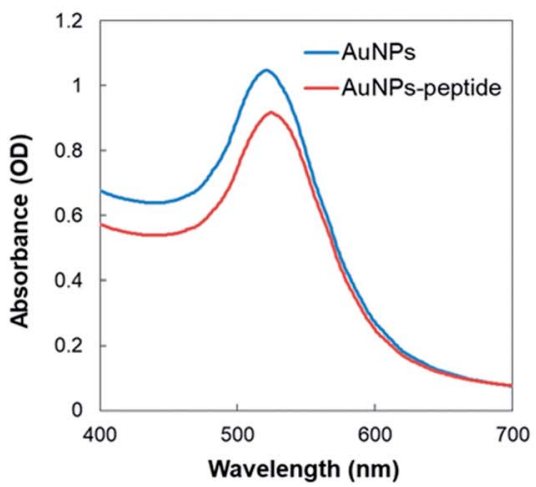

B. DLS of bare AuNPs

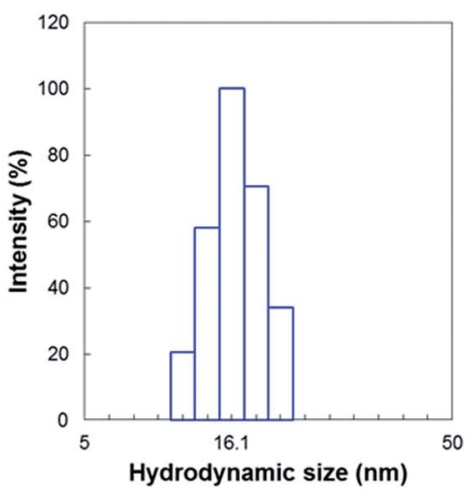

C. DLS of AuNPs-peptide

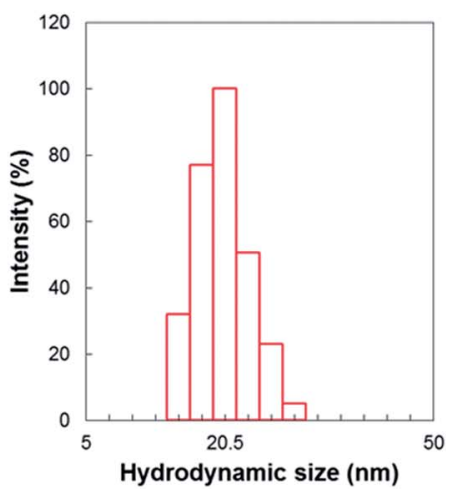

Fig. 1 UV spectra and DLS assays of bare AuNPs and AuNPs-peptide probe. (A) Maximum absorption peak of bare AuNPs located at 520 nm; AuNPs-peptide probe showed a red shift to about $525 \mathrm{~nm}$. (B) Average particle size of bare AuNPs was $16.1 \mathrm{~nm}$. (C) Average size of AuNPspeptide probe was $20.5 \mathrm{~nm}$. 


\section{A. SEM images}
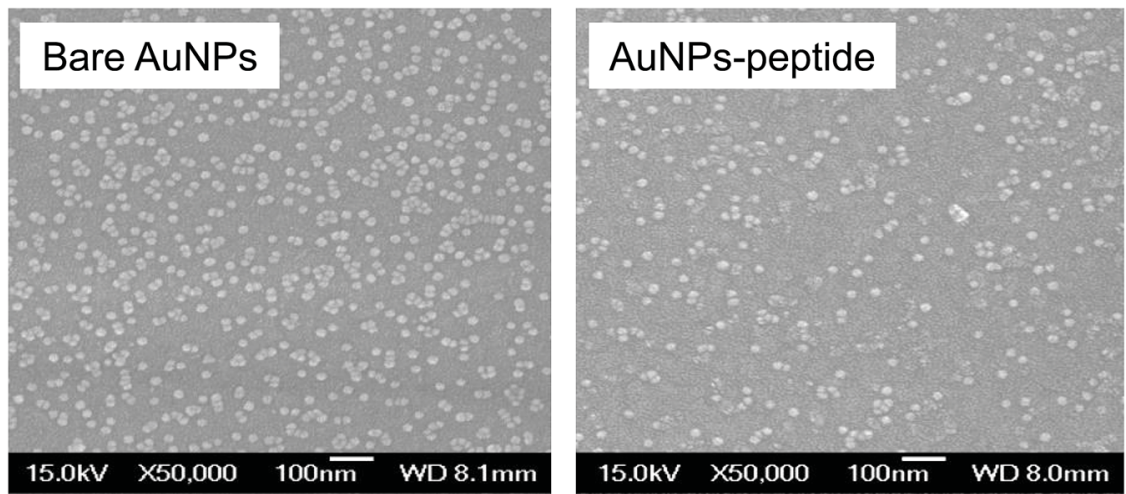

\section{B. AFM images}
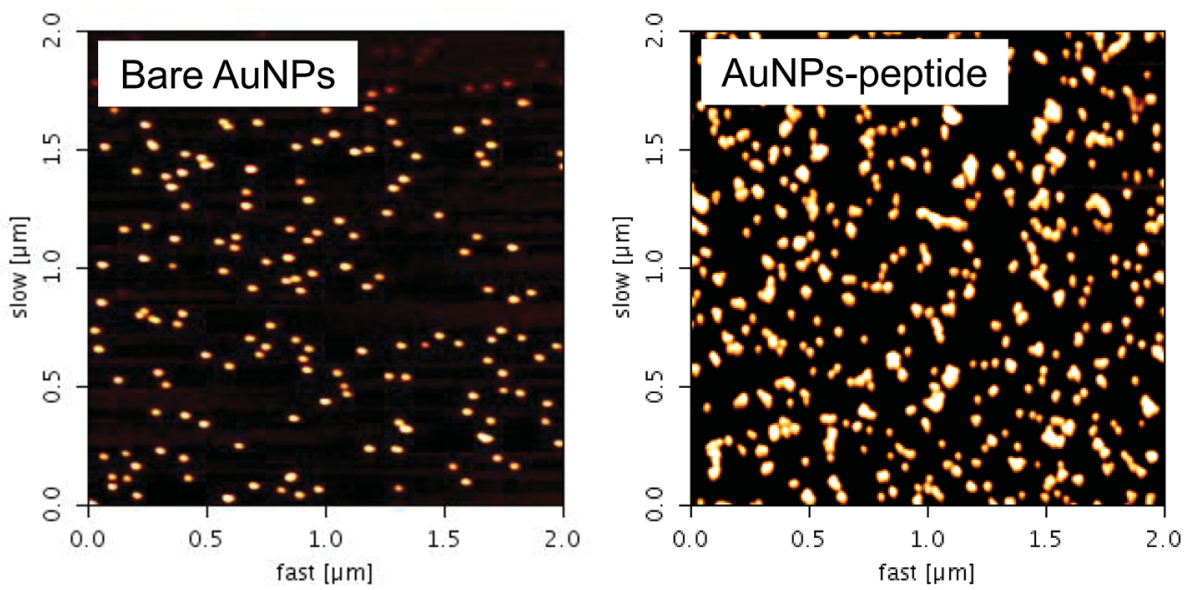

Fig. 2 SEM and AFM images of bare AuNPs and AuNPs-peptide. (A) Bare AuNPs and AuNPs-peptide were viewed by SEM with a JEM 100 CX electron microscope (JEOL Co. Ltd, Tokyo, Japan) at $25 \mathrm{kV}$. (B) Bare AuNPs and AuNPs-peptide were viewed by AFM with a Nanowizard ${ }^{\circledR}$ II AFM (JPK Instruments, Berlin, Germany).

pellets. The obtained supernatants were used for assays of chymase expression by Western blot and chymase enzyme activity. Protein concentration of the homogenous extract was measured by Bradford dye binding assay (Bio-Rad Laboratories, Hercules, CA, USA) with bovine serum albumin (BSA) as the standard.

Western blot for chymase protein expression was conducted as per our previous report. ${ }^{29}$ Aliquots containing $10 \mu \mathrm{g}$ kidney tissue proteins were electrophoresed on 10\% SDS-PAGE gels and then, the gels were transferred to polyvinylidene fluoride membranes (Immobilon-P ${ }^{\mathrm{TM}}$, Millipore, Bedford, MA, USA). Primary antibodies against protein were diluted $1: 2000$ for chymase and $\beta$-actin and secondary antibodies were diluted $1: 4000$. An enhanced chemiluminescent substrate for HRP detection was used (Western Lighting Plus-ECL, Enhanced Chemiluminescent Substrate; PerkinElmer, Boston, MA, USA) and the membranes were exposed to Lumi-Film Chemiluminescent Detection Film (Roche, Indianapolis, IN, USA). Bands on the images were detected at the anticipated locations based on size. The band intensity was quantified using Scion Image software (Scion, Frederick, MD, USA). The amounts of chymase were expressed relative to amount of $\beta$-actin (as internal standard) in detection.

\section{Statistical analysis}

All values were expressed as mean \pm standard deviation (SD). Statistical significance between the two groups was assessed by Student's $t$-test. For the $p$ value less than 0.05 , the differences were considered statistically significant.

\section{Results}

\section{Characteristics of synthesized AuNPs and AuNPs-peptide} probe

The 15-17 nm AuNPs were synthesized by citrate reduction method in this study. The original $\mathrm{OD}_{520}$ of the as-synthesized bare AuNPs was around 2; the $\mathrm{OD}_{520}$ was adjusted to about 1.0 for further peptide modification (Fig. 1A). Spectra of the assynthesized AuNPs were recorded by a UV spectrophotometer, and showed the SPR peak at $520 \mathrm{~nm}$. The size and 


\section{A. Image under white light}

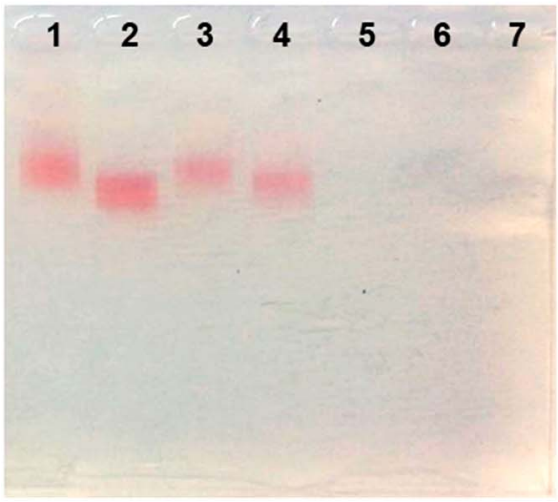

\section{B. Image under UV light}

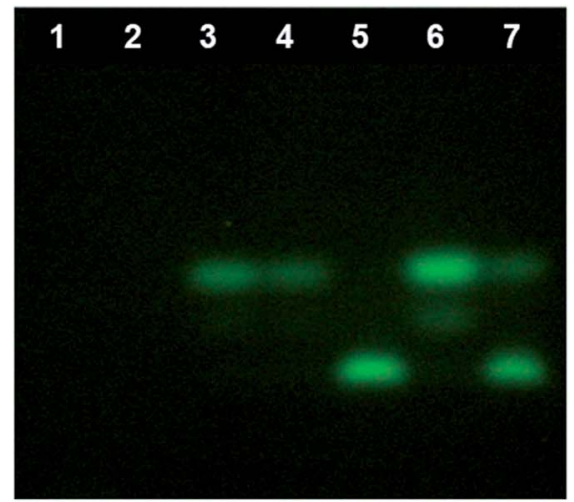

Fig. 3 Analysis of AuNPs and AuNPs-peptide probe by gel electrophoresis. (A) Gel is presented under white light and showed different migrations of bare AuNPs (lane 1), AuNPs-peptide probe (lane 2), AuNPs-peptide probe reacted with chymase (lane 3), AuNPs-peptide probe reacted with chymase and chymase inhibitor (lane 4), peptide (lane 5), peptide reacted with chymase (lane 6), and peptide reacted with chymase and chymase inhibitor (lane 7). (B) Gel shows excited fluorescence under UV light and demonstrates different fluorescence intensities and positions of peptide. Lane 3 and lane 6 were reacted with $100 \mathrm{ng} \mathrm{mL}^{-1}$ chymase for 15 min at $37^{\circ} \mathrm{C}$; lane 4 and lane 7 were reacted with $100 \mathrm{ng} \mathrm{mL}-1 \mathrm{chymase}$ and 50 $\mu \mathrm{M}$ chymostatin for $15 \mathrm{~min}$ at $37^{\circ} \mathrm{C}$. All samples were run in $1.5 \%$ agarose gel with horizontal electrophoresis system for $30 \mathrm{~min}$ at $110 \mathrm{~V}$ in working TBE buffer.

morphology of the as-synthesized AuNPs were examined by DLS and microscopy techniques. After conjugation of peptides onto AuNPs, the wavelength of maximum absorption shifted to a longer wavelength with respect to that of AuNPs (from 520 to $525 \mathrm{~nm}$ ) as a result of the capping of AuNPs surface with peptide molecules (Fig. 1A). Fig. 1B and $\mathrm{C}$ show that the average hydrodynamic diameters of bare AuNPs and AuNPspeptide probes were about $16.1 \mathrm{~nm}$ and $20.5 \mathrm{~nm}$, respectively. Sizes and morphologies of AuNPs and AuNPs-peptide were checked by scanning electron microscopy (SEM) (Fig. 2A) and atomic force microscopy (AFM) (Fig. 2B). To confirm the conjugation of peptide onto AuNPs, DTT-based displacement was used to permute the peptide conjugated onto AuNPs. The conjugation rate of the peptide onto AuNPs surface was generally $>50 \%$ for each preparation of AuNPspeptide probe.

\section{Gel electrophoresis analysis of AuNPs}

To study the morphology change of AuNPs after specific peptide modification and proteinase activation, the horizontal electrophoresis system was used to observe the change under white light and UV light. Fig. 3A shows different migration positions of bare AuNPs, AuNPs-peptide probe and the probe reacted with proteinase and proteinase inhibitor in white light. The observation under UV light (Fig. 3B) reveals that the pure peptide shows stronger excited fluorescence intensity than those modified onto AuNPs. The quenching effect of AuNPs is observed on lane 2 in Fig. 3B (AuNPs-peptide probe), and only slight fluorescence intensity appeared. However, significant fluorescence intensity was observed when AuNPs-peptide probe reacted with chymase (lane 3 in Fig. 3B). In addition, fluorescence intensity of lane 3 was stronger than the fluorescence intensity of lane 4 , indicating that the chymase inhibitor indeed worked effectively.
A. Reaction time

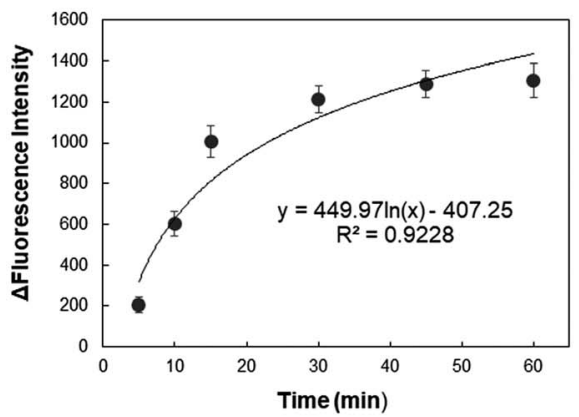

B. Reaction $\mathrm{pH}$

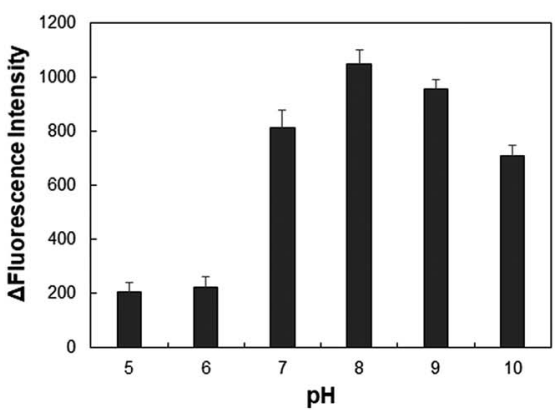

Fig. 4 Optimal conditions for detection of chymase activity. (A) AuNPs-peptide probe $(1.0 \mathrm{nM})$ was incubated with $100 \mathrm{ng} \mathrm{mL}^{-1} \mathrm{chymase}$ for different times ( 5 to $60 \mathrm{~min}$ ) at $37^{\circ} \mathrm{C}, \mathrm{pH} 8.0$. (B) AuNPs-peptide probe $\left(1.0 \mathrm{nM}\right.$ ) was incubated with $100 \mathrm{ng} \mathrm{mL}{ }^{-1} \mathrm{chymase}$ at different $\mathrm{pH}$ values (5 to 10) for $15 \mathrm{~min}$ at $37^{\circ} \mathrm{C}$. Error bars (SD) represent data from three independent detections. 


\section{Optimal reaction conditions of AuNPs-peptide probe}

Fig. 4A shows the AuNPs-peptide probe (1.0 nM) incubated with $100 \mathrm{ng} \mathrm{mL}{ }^{-1}$ chymase for different times $(5,10,15,30,45$, and $60 \mathrm{~min}$ ) at $37^{\circ} \mathrm{C}$ and $\mathrm{pH}$ 8.0. With incubation time of $15 \mathrm{~min}$, the increase in fluorescence intensity was about 1100fold. However, with the incubation time longer than $15 \mathrm{~min}$, the fluorescence intensity does not increase significantly. Fig. 4B shows the increased fluorescence intensity of AuNPspeptide probe $(1.0 \mathrm{nM})$ incubated with $100 \mathrm{ng} \mathrm{mL} \mathrm{m}^{-1}$ chymase at different $\mathrm{pH}$ values ( 5 to 10 ) for $15 \mathrm{~min}$ at $37^{\circ} \mathrm{C}$. The highest activity was detected at $\mathrm{pH} 8$, indicating that $\mathrm{pH} 8$ is the optimal $\mathrm{pH}$ condition for incubation. Therefore, the results indicate that the optimal reaction conditions for AuNPspeptide probe treated with chymase are $37{ }^{\circ} \mathrm{C}$ for $15 \mathrm{~min}$ at pH 8.

\section{Chymase activity assay by AuNPs-peptide probe}

The detection limit of the AuNPs-peptide probe was tested by incubating the probe with various concentrations of chymase $\left(0,10,20,40,60,80,100,125,150,200,300\right.$, and $\left.400 \mathrm{ng} \mathrm{mL} \mathrm{mL}^{-1}\right)$ for $15 \mathrm{~min}$ at $37^{\circ} \mathrm{C}$ and $\mathrm{pH}$ 8.0. Fig. 5 shows the clear linear correlation between 10 and $100 \mathrm{ng} \mathrm{mL}{ }^{-1}$ chymase, for which $y=$ $11.971 x-42.014$ and $R^{2}=0.9959$. Additionally, the detection limit of the AuNPs-peptide probe was calculated to be about 5 $\mathrm{ng} \mathrm{mL}^{-1}$ (signal/background noise $(\mathrm{S} / \mathrm{N}) \geq 3$ ).

Specificity test was performed using other serine proteinases, namely, chymotrypsin and trypsin. AuNPs-peptide probe was incubated with various concentrations of proteinases $(20$, $40,60,80$, and $100 \mathrm{ng} \mathrm{mL}{ }^{-1}$ ) for $15 \mathrm{~min}$ at $37^{\circ} \mathrm{C}$ and $\mathrm{pH}$ 8.0. The results in Fig. 6 show that fluorescence intensity significantly increases only after incubation with chymase. The increment in fluorescence intensity of AuNPs-peptide probe incubated with chymase increased was about 1250-fold. However, the

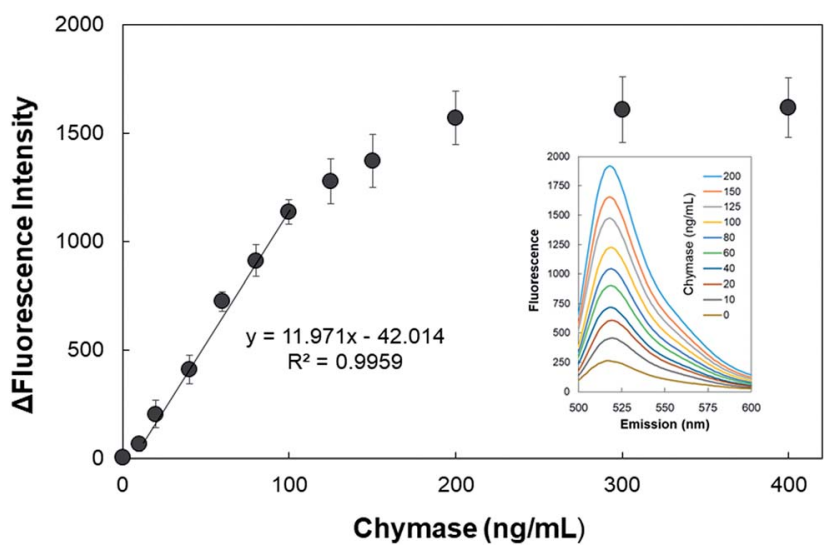

Fig. 5 Detection of chymase activity assay by AuNPs-peptide probe. AuNPs-peptide probe was incubated with various concentrations of chymase $\left(0-400 \mathrm{ng} \mathrm{mL}\right.$ ) for $15 \mathrm{~min}$ at $37^{\circ} \mathrm{C}, \mathrm{pH} \mathrm{8.0}$. The linear correlation between 10 and $100 \mathrm{ng} \mathrm{mL}^{-1}$ chymase was within confidence limits. Error bars (SD) represent data from three independent detections. The inserted figure shows fluorescence emission spectra of AuNPs-peptide probes activated by different concentrations of chymase.

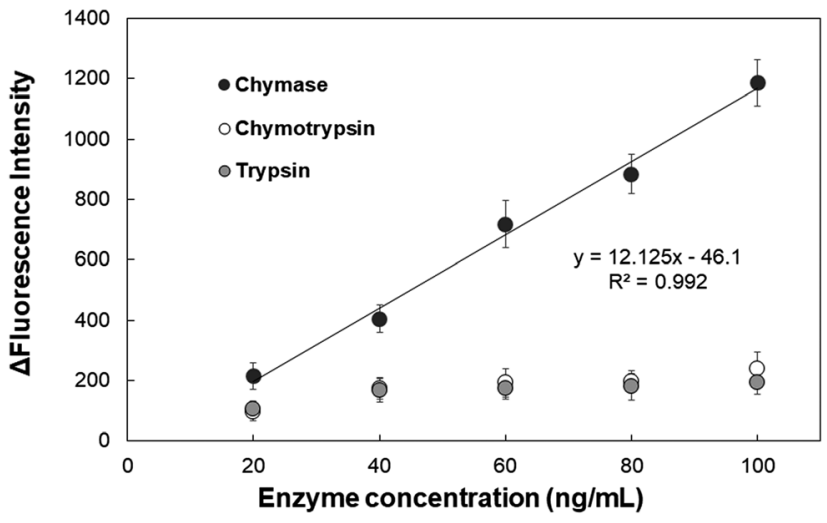

Fig. 6 Specificity assay of AuNPs-peptide probe for chymase activity. AuNPs-peptide probe was treated with various concentrations of proteinases $\left(20,40,60,80\right.$, and $\left.100 \mathrm{ng} \mathrm{mL}^{-1}\right)$ for $15 \mathrm{~min}$ at $37^{\circ} \mathrm{C}, \mathrm{pH}$ 8.0. Fluorescence intensity did not change significantly after treatment with chymotrypsin or trypsin; fluorescence intensity significantly increased after treatment with chymase for $15 \mathrm{~min}$. Error bars (SD) represent data from three independent detections.

increment in fluorescence intensities of AuNPs-peptide probe incubated with chymotrypsin and trypsin was not significant.

\section{Chymase inhibition assay with AuNPs-peptide probe}

To study the inhibitory effect of chymase, the chymase inhibitor chymostatin was used in this experiment. AuNPs-peptide probe was incubated with $80 \mathrm{ng} \mathrm{mL}^{-1}$ chymase and various concentrations of chymostatin $(0,5,10,15,20,25$ and $50 \mu \mathrm{M})$ for $15 \mathrm{~min}$ at $37^{\circ} \mathrm{C}$ and $\mathrm{pH}$ 8.0. The results in Fig. 7A show that 80 ng $\mathrm{mL}^{-1}$ chymase was significantly inhibited by $15 \mu \mathrm{M}$ chymostatin. However, Fig. 7B shows that only $80 \%$ chymase activity could be inhibited even when a high concentration of chymostatin $(50 \mu \mathrm{M})$ was added. The calculated $\mathrm{IC}_{50}$ value was approximately $12.5 \mu \mathrm{M}$ of chymostatin for inhibition of chymase activity.

\section{Detection of chymase activity in kidney tissue}

Animal study of AAI-induced kidney injury was performed; urine, serum, and kidney tissue were sampled for observing the development of progressive nephropathic disease. The levels of serum creatinine were significantly increased in mice with AAI administration. Increased urine protein and serum BUN levels were also observed in mice after AAI treatment (ESI Fig. S2 $\dagger$ ). In the kidney tissue, significantly infiltrating inflammatory cells, intrarenal fibrosis and severe interstitial tissue damage in AAI treated mice were observed (ESI Fig. S3†). These results indicate that nephropathy of mice was successfully induced by AAI administration. Increased renal chymase activity in AAI-treated mice was detected along with the increased chymase expression in the kidney tissue. Renal chymase protein expression (Fig. 8A), chymase activity in kidney (Fig. 8B) and chymase activity in blood (Fig. 8C) displayed 2.2-, 3.0- and 1.3-fold increase, respectively, in mice treated with AAI compared with those in the Sham control group. 
A. Change of fluorescence intensity

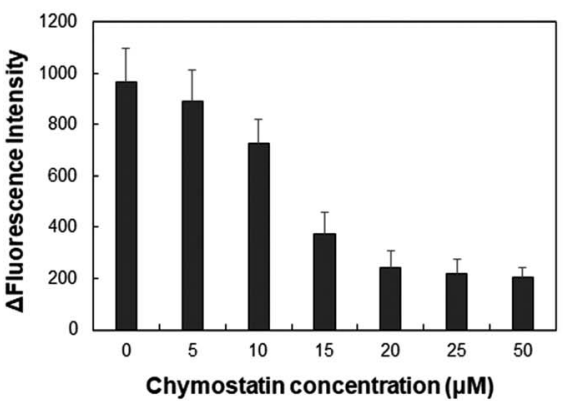

B. Inhibition rate

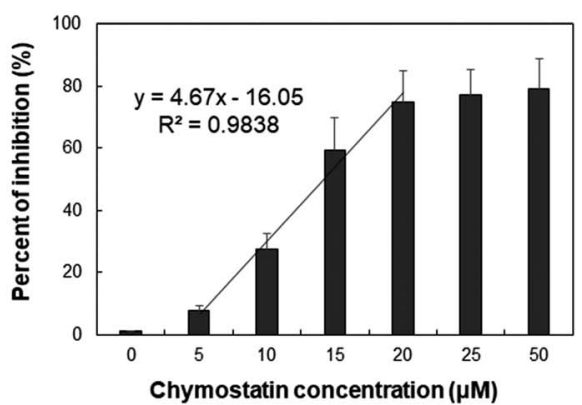

Fig. 7 Chymase inhibition assay by chymostatin, a specific chymase inhibitor. (A) AuNPs-peptide probe was incubated with 80 ng $\mathrm{mL}^{-1} \mathrm{chymase}$ and various concentrations of chymostatin $(0,5,10,15,20,25$ and $50 \mu \mathrm{M})$ for $15 \mathrm{~min}$ at $37^{\circ} \mathrm{C}, \mathrm{pH} 8.0$. Significant inhibition can be detected with $15 \mu \mathrm{M}$ chymostatin added. (B) Inhibitory effect is expressed as percent. Almost $50 \%$ chymase activity was inhibited by about $12.5 \mu \mathrm{M}$ chymostatin $\left(\mathrm{ID}_{50}\right)$. Linear correlation from $5 \mu \mathrm{M}$ to $20 \mu \mathrm{M}$ of chymostatin was confident for inhibition of chymase activity. Error bars (SD) represent data from three independent detections.

A. Chymase expression

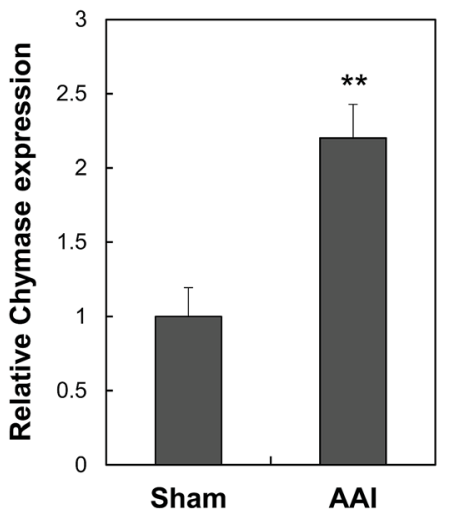

B. Chymase activity in kidney

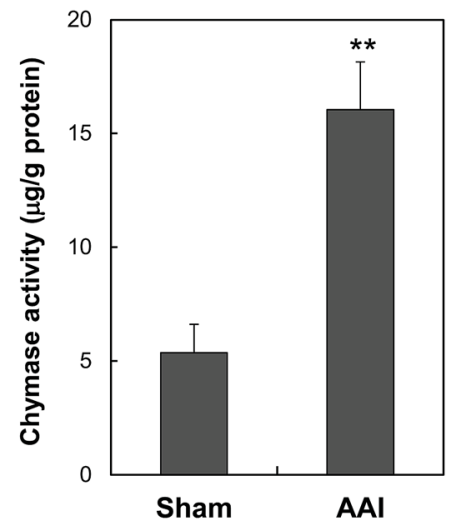

C. Chymase activity in serum

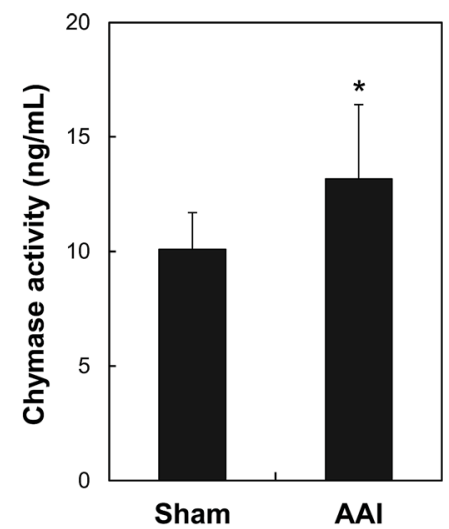

Fig. 8 Expression of chymase protein and chymase activity in kidney tissue and blood. (A) Renal chymase expression, (B) chymase activity in kidney, and (C) chymase activity in blood in AAl-treated mice were significantly higher than those in Sham group. All values were expressed as mean \pm SD from each group $(n=9)$. ** indicates $p<0.01$ compared with the Sham group.

\section{Discussion}

In this study, we successfully constructed a self-assembled AuNPs fluorescent peptide probe (AuNPs-peptide probe), which comprises a specific fluorophore (FITC-labeled) peptide and a quencher (AuNPs)..$^{9,30}$ The detection time of this AuNPspeptide probe for activity detection of chymase is only $15 \mathrm{~min}$, and a linear correlation from 10 to $100 \mathrm{ng} \mathrm{mL}^{-1}$ of chymase was acquired. Moreover, the detection limit of the AuNPs-peptide probe is about $5 \mathrm{ng} \mathrm{mL}^{-1}$. The detection sensitivity is comparable to those of a label-free fluorometric detection of chymotrypsin activity using AuNPs, graphene oxide/DNA-stabilized silver nanoclusters, and 1,8-naphthalimide-based ratiometric fluorescence probe. ${ }^{7,31,32}$

AuNPs with size of around 10-20 $\mathrm{nm}$ and having potentially high quenching ability were applied to conjugate with the designed fluorescent peptide probe.$^{6-8}$ Length and charge of the peptide were considered based on the negatively charged surface of the citrate-capped AuNPs. ${ }^{7,33}$ It is well known that conjugating with adequate ligands can improve the stability of AuNPs, and the stabilizing effect can be increased with the increase in length of the peptide. However, longer peptides may be broken easily, causing increased background for detection. Suitable length and charge are needed for stability and sensitivity of AuNPs-peptide probe. Moreover, the length of substrate sequence and hydrophobicity may affect the efficiency of target hydrolysis and the stability of peptide conjugation with AuNPs. ${ }^{6,8}$

In the design of AuNPs-peptide probe, the desired peptides usually comprise an anchoring group to conjugate to AuNPs surface, a spacing group to enhance the signals of detection, a backbone (usually the substrate sequence), and a terminal functional group (such as fluorophores). ${ }^{15}$ The thiol group has strong affinity with AuNPs and cysteine (C) is most commonly used to conjugate with AuNPs. ${ }^{16,31}$ As evidenced by the results of our previous study, ${ }^{7}$ the spacing group of a designed peptide can significantly enhance the detection sensitivity. Five negatively charged amino acid molecules, namely aspartic acid (D) molecules, conjugated onto the AuNPs colloid, could increase 
the stability of the peptide-capped AuNPs and avoid AuNPs aggregation by increasing electrostatic repulsion between the peptides. ${ }^{13,33}$ Moreover, negative charge on the spacer peptide could allow a well packed layer of peptides on the AuNP surface to increase enzyme access to the cleavage site.

Electrophoresis of agarose gel is a useful tool to easily monitor the AuNPs modified with biological molecules, such as nucleic acids, antibodies and proteins. ${ }^{34-36}$ Based on the negatively charged AuNPs and peptide, the results of gel electrophoresis showed that migration of the peptide sequence cleaved by chymase was shorter than that of the original peptide (Fig. 3). Mobility of citrate-capped AuNPs increased upon modification with negatively charged peptides (AuNPs-peptide probe). The predicted cleavage site in the original peptide was Phe (F)-|-His $(\mathrm{H})$, which divided the peptide into two. Without the negatively charged spacer, the remaining peptide, whose charge increased but was still negative, migrated a shorter distance compared with the original peptide. The quenching ability of AuNPs was also observed in this experiment. The original peptide conjugated onto AuNPs without enzyme catalysis did not show a fluorescence band in the gel.

Overall peptide charge is also considered based on the Derjaguin-Landau-Verwey-Overbeek (DLVO) theory. This theory describes the stability of nanoparticles in a suspension depending on surface charge and the effects of electrostatic repulsion and van der Waals attraction forces between nanoparticles. ${ }^{37,38}$ The double layer of counter ions formed results from the surface charge of nanoparticles, which prevents aggregation between nanoparticles. It is found that only negatively charged peptides modified onto AuNPs remain stable because the surface charge of AuNPs synthesized by citrate method is negative. ${ }^{38,39}$ Modifying cationic peptides onto AuNPs causes aggregation due to the bridging effect with citrate ions. ${ }^{40}$

In order to investigate the practicability in experimental as well as clinical studies, we used the as-synthesized AuNPspeptide probe to detect chymase activity in kidney tissue of experimental animals. Though the detectable range of chymase was only from 10 to $100 \mathrm{ng} \mathrm{mL}^{-1}$, it was sufficient for us to detect chymase activity in kidney tissue. The AuNPs-peptide probe could also be used to detect chymase activity of various visceral tissue homogenates and blood (ESI Table S2†). Normal renal chymase activity was about $5 \mu \mathrm{g} \mathrm{g}^{-1}$ protein of tissue homogenate and $10 \mathrm{ng} \mathrm{mL}^{-1}$ of blood, and chymase activity in kidney tissue and blood significantly increased in the mice treated with AAI. The physiological and biochemical determinations indicated that nephropathy was induced in mice treated with AAI. In kidney tissue sections, high amounts of inflammatory cells and fibrosis in interstitial tissue were observed. Most importantly, there was significantly increased chymase activity in kidney tissues of AAI-treated mice. The present results demonstrate that renal chymase might play an important role in ACE-independent Ang II generation in nephropathy progression. ${ }^{19-21}$ Additionally, we have established a useful and sensitive method to detect cellular and tissue chymase activity, which is desirable given the multifunctional role of chymase in acute and chronic tissue injury as well as remodeling of human diseases. ${ }^{41}$

\section{Conclusion}

In this study, an AuNPs-based fluorescence peptide probe was successfully synthesized and applied in detection of chymase activity in kidney tissue. The peptide was designed to be negatively charged for stability. Due to the negative surface charge of citrate-synthesized AuNPs, negatively charged peptides could prevent the aggregation between AuNPs and decrease the spatial barrier for enzyme catalyzation. Increased length of peptide enhances the fluorescence signal and increases stability. Moreover, the negatively charged spacer has been proved more suitable than a positively charged or neutral spacer. Furthermore, the established biosensing strategy can be extended to other proteinases by use of different peptide substrates, i.e., by changing the substrate sequence of amino acids. Thus, the technique of AuNPs-peptide probe can be applied for several purposes, such as drug targeting methodology and diagnosis of diseases.

\section{Author contributions}

H. F. and Y. L. prepared the article and discussed the experimental data. F. Y. and I. H. performed the laboratory and animal experiments. C. C. and C. S. designed the study and supervised the project, and reviewed the article.

\section{Conflicts of interest}

The authors declare no competing financial interest.

\section{Acknowledgements}

This work was supported by the grant of MOST 104-2313-B-009001-MY3 and MOST 107-2313-B-009-002-MY3 from the Ministry of Science and Technology (MOST), Taiwan. This work was supported by the grant of MMH-CT-10702 from the Hsinchu Mackay Memorial Hospital, Taiwan. This work was also financially supported by the "Center For Intelligent Drug Systems and Smart Bio-devices ( IDS $\left.^{2} \mathrm{~B}\right)$ " from The Featured Areas Research Center Program within the framework of the Higher Education Sprout Project of the National Chiao Tung University and Ministry of Education (MOE), Taiwan.

\section{References}

1 J. Wolfram, M. Zhu, Y. Yang, J. Shen, E. Gentile, D. Paolino, M. Fresta, G. Nie, C. Chen, H. Shen, M. Ferrari and Y. Zhao, Curr. Drug Targets, 2015, 16, 1671-1681.

2 M. Rai, A. P. Ingle, S. Birla, A. Yadav and C. A. Santos, Crit. Rev. Microbiol., 2016, 42, 696-719.

3 Q. Liu, N. Li, M. Wang, L. Wang and X. Su, Anal. Chim. Acta, 2018, 1013, 71-78.

4 H. Jans and Q. Huo, Chem. Soc. Rev., 2012, 41, 2849-2866.

5 L. Nie, F. Liu, P. Ma and X. Xiao, J. Biomed. Nanotechnol., 2014, 10, 2700-2721. 
6 H. Y. Hu, S. Gehrig, G. Reither, D. Subramanian, M. A. Mall, O. Plettenburg and C. Schultz, Biotechnol. J., 2014, 9, 266281.

7 F. Y. Yeh, I. H. Tseng, S. H. Chuang and C. S. Lin, RSC Adv., 2014, 4, 22266-22276.

8 Q. Wang, W. Hu, Q. Feng, X. H. Cao, W. Chai, C. Yi and M. J. Li, RSC Adv., 2015, 5, 43824-43830.

9 Principles of Fluorescence Spectroscopy, ed. J. R. Lakowicz, Springer Science \& Business Media, 2013, pp. 443-475.

10 J. Shi, C. Chan, Y. Pang, W. Ye, F. Tian, J. Lyu, Y. Zhang and M. Yang, Biosens. Bioelectron., 2015, 67, 595-600.

11 Y. H. Lin, S. H. Chen, Y. C. Chuang, Y. C. Lu, T. Y. Shen, C. A. Chang and C. S. Lin, Biosens. Bioelectron., 2008, 23, 1832-1837.

12 Y. C. Chuang, W. T. Huang, P. H. Chiang, M. C. Tang and C. S. Lin, Biosens. Bioelectron., 2012, 32, 24-31.

13 G. Chen, Y. Xie, H. Zhang, P. Wang, H. Y. Cheung, M. Yang and H. Sun, RSC Adv., 2014, 4, 6560-6563.

14 D. Aili, K. Enander, J. Rydberg, I. Nesterenko, F. Björefors, L. Baltzer and B. Liedberg, J. Am. Chem. Soc., 2008, 130, 5780-5788.

15 E. Oh, K. Susumu, A. J. Mäkinen, J. R. Deschamps, A. L. Huston and I. L. Medintz, J. Phys. Chem. C, 2013, 117, 18947-18956.

16 X. Liu, M. Marrakchi, D. Xu, H. Dong and S. Andreescu, Biosens. Bioelectron., 2016, 80, 9-16.

17 S. Park, B. J. Bivona, S. M. Jr Ford, S. Xu, H. Kobori, L. de Garavilla and L. M. Harrison-Bernard, Hypertension, 2013, 61, 465-471.

18 J. N. Lorenz, Am. J. Physiol.: Renal, Fluid Electrolyte Physiol., 2010, 298, F35-F36.

19 X. R. Huang, W. Y. Chen, L. D. Truong and H. Y. Lan, J. Am. Soc. Nephrol., 2003, 7, 1738-1747.

20 Y. Konishi, T. Morikawa, N. Okada, I. Maeda, C. Kitabayashi, K. Yoshioka, M. Okumura, A. Nishiyama, M. Ueda, S. Takai, M. Miyazaki and M. Imanishi, Hypertens. Res., 2008, 8, 15171524.

21 P. C. Cristovam, A. K. Carmona, C. P. Arnoni, E. Maquigussa, L. G. Pereira and M. A. Boim, Exp. Biol. Med., 2012, 8, 985992.

22 Y. Li, L. Zhou, F. Liu, Y. Peng, J. Li, L. Sun, S. Duan, G. Ling, X. Chen, W. Jiang and Y. Xia, Kidney Blood Pressure Res., 2010, 33, 240-248.

23 H. Wasse, N. Naqvi and A. Husain, Curr. Hypertens. Rev., 2012, 8, 15-23.
24 M. N. Greco, M. J. Hawkins, E. T. Powell, H. R. Jr Almond, L. de Garavilla, J. Hall, L. K. Minor, Y. Wang, T. W. Corcoran, E. Di Cera, A. M. Cantwell, S. N. Savvides, B. P. Damiano and B. E. Maryanoff, J. Med. Chem., 2007, 50, 1727-1730.

25 Y. Soga, S. Takai, T. Koyama, Y. Okamoto, T. Ikeda, K. Nishimura, M. Miyazaki and M. Komeda, J. Thorac. Cardiovasc. Surg., 2004, 127, 72-78.

26 K. Fujimi, Y. Uehara, S. Abe, A. Kawamura, S. Devarajan, S. Miura, K. Saku and H. Urata, Hypertens. Res., 2010, 33, 149-154.

27 Y. C. Chuang, J. C. Li, S. H. Chen, Y. U. Liu, C. H. Kuo, W. T. Huang and C. S. Lin, Biomaterials, 2010, 31, 6087-6095.

28 D. H. Tsai, M. P. Shelton, F. W. DelRio, S. Elzey, S. Guha, M. R. Zachariah and V. A. Hackley, Anal. Bioanal. Chem., 2012, 404, 3015-3023.

29 Y. H. Hung, W. Y. Hsieh, J. S. Hsieh, F. C. Liu, C. H. Tsai, L. C. Lu, C. Y. Huang, C. L. Wu and C. S. Lin, Int. J. Biol. Sci., 2016, 12, 454-465.

30 E. Dulkeith, M. Ringler, T. A. Klar, J. Feldmann, A. Munoz Javier and W. J. Parak, Nano Lett., 2005, 5, 585-589.

31 S. Li, Y. Fu, X. Ma and Y. Zhang, Biosens. Bioelectron., 2017, 88, 210-216.

32 Y. Chen, J. Cao, X. Jiang, Z. Pan and N. Fu, Sens. Actuators, B, 2018, 273, 204-210.

33 J. A. Tullman, W. F. Finney, Y. J. Lin and S. W. Bishnoi, Plasmonics, 2007, 2, 119-127.

34 S. H. Chen, K. I. Lin, C. Y. Tang, S. L. Peng, Y. C. Chuang, Y. R. Lin, J. P. Wang and C. S. Lin, IEEE Trans. Nanobioscience, 2009, 8, 120-131.

35 F. Y. Yeh, T. Y. Liu, I. H. Tseng, C. W. Yang, L. C. Lu and C. S. Lin, Biosens. Bioelectron., 2014, 61, 336-343.

36 Y. C. Chuang, W. T. Huang, P. H. Chiang, M. C. Tang and C. S. Lin, Biosens. Bioelectron., 2012, 32, 24-31.

37 B. Derjaguin and L. Landau, Prog. Surf. Sci., 1993, 43, 30-59.

38 K. D. Lee, S. Nir and D. Papahadjopoulos, Biochemistry, 1993, 32, 889-899.

39 Ş. Kalay, C. Blanchet and M. Culha, Turk. J. Chem., 2014, 38, 686-700.

40 Ž. Krpetić, P. Nativo, F. Porta and M. Brust, Bioconjug. Chem., 2009, 20, 619-624.

41 L. J. Dell'Italia, J. F. Collawn and C. M. Ferrario, Circ. Res., 2018, 122, 319-336. 